\title{
Immunological and Molecular Diagnosis of Cytomegalovirus Infection between Aborted \& Pregnant Women in Babylon City
}

\section{Qabas Neamah AL-Hajjar}

\author{
Haider Turky Mousa Al-Mousawi *
}

${ }^{1}$ Faculty of Pharmacy, Kufa University, AL-Najaf, Iraq.

${ }^{2}$ Al-Qasim Green University, College of biotechnology, Babylon, Iraq

"Corresponding author: qabasn.hadi@uokufa.edu.iq, dr.haideralmusawi@biotech.uoqasim.edu.iq*

*ORCID ID: https://orcid.org/0000-0001-9292-4611

Received 5/1/2020, Accepted 18/11/2020, Published 20/6/2021

This work is licensed under a Creative Commons Attribution 4.0 International License.

\begin{abstract}
:
Human cytomegalovirus (CMV) is the globally highly prevalent herpesvirus worldwide. CMV infects populations of all ages according to the Center for Disease Control and Prevention (CDC) and World Health Organization (WHO). CMV infections remain the most common viral complication potentially multiple in humans and are a major cause of congenital normality in women, which is why they are critical for diagnosis in several times when it happens during pregnancy. Pregnant women with CMV infection can be in charge of abortion or congenital expandaedby. This study involves the collection a total of (90) samples taken from each aborted and pregnant woman (70 with abortion cases and 20 of pregnant without history of abortion as control subjects) referring to Babylon teaching hospital for Maternity and Children, covering a period from (October 2018 to March 2019) to investigate the occurrence of Cytomegalovirus (CMV) in Babylon city. Patients and controls were evaluated for IgG, IgM antibodies and anti-HCMV IgG, IgM for (90) subjects were controlled in this study using the Enzyme Immunoassay Test Kit and read by enzyme - linked immunosorbent analyze (ELISA). In addition the polymerase chain reaction (PCR) DNA detection for CMV are based on the amplification of pathogen genomes in a particular region using different primers. The Chi-square test was used to analyze the data. The results show among 90 samples, women were evaluated for CMV infection, the seroprevalence titer was significantly higher at $\mathrm{P}<0.05$ in seropositive cases ranging from $62(89 \%)$ toward positive CMV IgG, while the $65(93 \%)$ of patients were positive CMV IgM from (70) women with abortions. By contrast, the results obtained from the controls were $9(45 \%)$ subjects seropositive for IgG and all of them were seronegative with IgM. The anti - HCMV IgG finding showed high positivity that represents the furthermost of CMV infections among females through ages ranging between 20-29 years. Furthermore, the outcomes of molecular detection showed that a small number of samples $13(19 \%)$ were HCMV DNA detectable in aborted women less than in pregnant women 3 (15\%).
\end{abstract}

Key words: Abortion, Anti-HCMV, IgG Human cytomegalovirus (HCMV), IgG \&IgM antibodies, IgM and HCMV DNA.

\section{Introduction:}

Human cytomegalovirus (HCMV) as an opportunistic pathogen is also known as the omnipres ent herpes virus (Human Herpes Virus 5) from the characteristic cytomegalic appearance of intra-nuclear inclusions in most cell types and organs, with the highest morbidity and mortality rates compared with other herpes virus, with genomes consisting of mono partite, linear, double-stranded DNA and is roughly $235 \mathrm{kbp}$ size capable of a wide spectrum of disease in humans (1). Miscarriage has been attributed to many important causes related to in human reproduction such as infectious agents, abnormalities from genetic and uterine, immunological dysfunctions and endocrine, environmental pollutants, psychogenetic factors and endometriosis (2) . Any severe maternal infection which leads to bacteremia or viremia can cause lapse. 
The recurrence of pregnancy waste due to maternal infections spread in the uterus at various gestational stages may be caused by a wide range of pathogens, including the TORCH complex (Toxoplasma gondii, Rubella virus, Cytomegalovirus and Herpes simplex virus) (3, 4). These entire infective agents induce a shift of responding of the immunity through pregnancy from Th2 to Th1 with apoptosis which can be experiential clinical as abortion progression (5). The range of spontaneous abortion from infectious of fetal by the infection agents like TORCH is believed to average from 10$15 \%$.

The greatest occurrences of the HCMV infections have been reported for pregnant women and women of childbearing stage from dissimilar foci in the parts of Eastern/Central Europe, Latin America, the Middle East, parts of south - East Asia and Africa (6). The HCMV remains a common virus that infects people of all ages. HCMV has a ubiquitous distribution; the range between $40-100 \%$ of all adults is carrying the virus worldwide (7). Infectious agents can contribute to impair human functions including reproduction. Viruses were able to interfere with the reproductive function in both sexes. The CMV virus is transmission by close contacts among infected subjects, via such as blood or blood products, congenital, sexual intercourse (8). Infections for congenital HCMV are mostly noted as causes of hearing loss and mental retardation; latent CMV infections can be activated in immune compromised patients, e.g. with immunosuppressed transplant receivers or AIDS.

The aims of this study are to investigate the role of some microbial infections such as Cytomegalovirus infection in aborted and pregnant women. This objective was carried out by the following objectives: Microbial agents detection of such as (IgM, $\operatorname{IgG}$ ) Cytomegalovirus and by ELISA Technique and Genetic detection of Cytomegalovirus DNA in collected samples.

\section{Materials and Methods: Clinical Samples}

Blood and plasma samples have been obtained as 90 women (70 patients travail from spontaneous abortion and 20 pregnant women as a comparable group) during the period from October 2018 to March 2019 at consultant clinic for infertile women in Babylon (Babil Teaching Hospital for Maternity and children). The patients and pregnant women ages ranged from 15 to 45 years old was represent to $\mathrm{Al}$ Hillah Counsellor Clinic meant for infertile women.

\section{Ethical criteria}

Assignments were made and all samples were obtained from abortion and pregnant women, and the doctors after they had received their consent.

\section{Kits}

The kits used for this analysis are shown in Table1.

Table 1. Kit forms cast-off in the present study

\begin{tabular}{ccc}
\hline No. & kits types & Land / Company \\
\hline 1 & Wiz Prep TM Viral DNA / RNA $^{\text {Mini Kits (Plus) }}$ & Korea \\
2 & PCR premix 25 $\mu$ l reaction & Korea \\
& $\begin{array}{c}\text { ELISA to evaluate the } \\
3\end{array}$ & oncentrations of IgM and IgG for \\
& CMV and HSV IgM & USA \\
\hline
\end{tabular}

\section{Sample Collection}

Blood sample from aborted mother $(5 \mathrm{ml})$ were collected, $2 \mathrm{ml}$ of the $5 \mathrm{ml}$ were collected by EDTA tubes for genetic study and the rest $3 \mathrm{ml}$ were put in the tubes made of plastic or (gel tube), and centrifugation of blood samples for 5 minutes at 4,000 rpm, collection of the serum in plastic tubes (plane tubes) for ELISA test. Serum remains stable for 4 hours at $20 \pm 50{ }^{\circ} \mathrm{C}$.

\section{Serological Detection for Cytomegalovirus (CMV) IgM, IgG ELISA:}

All serum samples were estimate the concentration of levels for virus-specific CMV IgG \& IgM antibodies and Anti-IgG \& IgM markers using enzyme immunoassay test kit according to the manufacturer's instructions and reading pf the O.D. at $450 \mathrm{~nm}$ within $15 \mathrm{~min}$ by using Enzyme-linked immune sorbent assays (ELISA) technique.

\section{Preparation of Chemicals}

The preparation of $1 \mathrm{X}$ wash buffer was done by adding the content of the bottle $(25 \mathrm{ml}, 20 \mathrm{X})$ to $475 \mathrm{ml}$ of deionized water. Then it was stored in room temperature $\left(20-25^{\circ} \mathrm{C}\right)$.

\section{Extraction of Genomic DNA from blood for CMV PCR}

The process was attained according to the method recommended by the DNA Blood Min Kit manufacturing company for isolated of viral DNA according to kits.

\section{PCR Reaction for DNA detection.}

Detection of HCMV DNA by polymerase chain reaction (PCR) was performed using special primers to amplify pathogen genomes in specific regions. DNA amplifications were performed in a 
final mixture of $25 \mu \mathrm{l}$ reactions for the $\mathrm{CMV}$ as shown in Table 2.This assay was done according to the method by (9).

Table 2. Contents of Mixed Reactions

\begin{tabular}{lll}
\hline No & Content & Volumes \\
\hline 1 & Master mix & $10 \mathrm{ul}$ \\
2 & Forward primer & $1 \mathrm{ul}$ \\
3 & Reverse primer & $1 \mathrm{ul}$ \\
4 & Patient DNA template & $3 \mathrm{ul}$ \\
5 & Nuclease free Water & $10 \mathrm{ul}$ \\
& Total Volumes & $\mathbf{2 5} \mathbf{~ u l}$ \\
\hline
\end{tabular}

\section{Primers used in PCR Technique}

The One primer pairs of oligo-nucleotide used in this study has been published previously and specifically supported amplification of CMV. According to the previous study, the outer sequences of the primers were chosen from the conserved fourth exon regions for instant early gene detection at the HCMV. The primers were supplied by (Bioneer Company, Korea), as shown in Table 3.

The thermal cycling conditions were done according to the method by (10), and as shown in Table (4).

Table 3. Primers Used in this Study

\begin{tabular}{|c|c|c|c|c|}
\hline $\begin{array}{l}\text { Primer } \\
\text { Name }\end{array}$ & $\begin{array}{l}\text { Primer } \\
\text { Sequence } \\
\text { Oligo sequence } \\
\text { F }\left(5^{\prime} \rightarrow 3^{\prime}\right) \\
\text { Forward }\end{array}$ & $\begin{array}{l}\text { Primer } \\
\text { Sequence } \\
\text { Oligo } \\
\text { sequence R } \\
\left(5^{\prime} \rightarrow 3^{\prime}\right) \\
\text { Reverse }\end{array}$ & $\begin{array}{c}\text { Product } \\
\text { si (bp) }\end{array}$ & Ref \\
\hline $\begin{array}{l}\text { CMV } \\
D N A\end{array}$ & $\begin{array}{l}\text { GGATCCGCA } \\
\text { TGGCATTCA } \\
\text { CGTATGT }\end{array}$ & $\begin{array}{l}\text { GAATTCA } \\
\text { GTGGATA } \\
\text { ACCTGCG } \\
\text { GCGA }\end{array}$ & 406 & (10) \\
\hline
\end{tabular}

Table 4. Thermal cycling conditions for PCR detection

\begin{tabular}{lllc}
\hline $\begin{array}{l}\text { CMV Gene detection } \\
\text { Steps Type }\end{array}$ & Temperatures & Times & Cycle \\
\hline Initial Denaturation & $\mathbf{9 5}{ }^{\circ} \mathrm{C}$ & $\mathbf{1 0} \mathrm{min}$ & $\mathbf{1}$ \\
Denaturation & $95^{\circ} \mathrm{C}$ & $45 \mathrm{Sec}$ & $\mathbf{3 5}$ \\
Annealing & $\mathbf{6 1}^{\circ} \mathrm{C}$ & $\mathbf{5 0} \mathrm{Sec}$ & $\mathbf{3 5}$ \\
Extension & $\mathbf{7 2}^{\circ} \mathrm{C}$ & $45 \mathrm{Sec}$ & $\mathbf{3 5}$ \\
Final Extension & $\mathbf{7 2}^{\circ} \mathrm{C}$ & $5 \mathrm{~min}$ & $\mathbf{3 5}$ \\
Hold & $4^{\circ} \mathrm{C}$ & $\alpha$ & 1 \\
\hline
\end{tabular}

\section{Measurement of Purity and Concentration of DNA}

Quantification of genomic CMV DNA was determined using a spectrophotometrically (Nanodrop) instrument to measure the optical density (O.D) (10).

\section{Agarose electrophoresis}

The amplification of PCR products was isolated by $1.5 \%$ agarose gel electrophoresis, stained with safe red, and visualized by transiluminator with ultra-violate (UV). In a nutshell, the agarose gel was prepared by dissolving $1.5 \mathrm{gm}$ of agarose powder in $100 \mathrm{ml}$ of sterile $1 \mathrm{X}$ TBE buffer at $(\mathrm{pH}: 8)$ in water bath, allowed to cool to $50^{\circ} \mathrm{C}$ and additing a stain of safe red was on the $5 \mu 1$ at the concentration of 0.5 $\mathrm{mg} / \mathrm{ml}$. The comb was fixed at one end of the tray for making wells used for loading DNA sample. The agarose was gently poured into the tray and allowed to solidify for $30 \mathrm{~min}$ at room temperature. Then, the comb was gently removed from the tray. The tray was fastened in an electrophoresis chamber filled with a TBE buffer covering the surface of the gel, $5 \mu 1$ of the amplified sample was loaded into the wells in agarose gel, and in one, and well we put the $5 \mu \mathrm{l}$ of the DNA ladder. The electric current has been allowed for 45 min at 100 volt. E-graph gel recording system has been used to track DNA bands and captures gel images (11).

\section{Statistical Analysis}

The resulted data were analyzed using the computer Statistical analysis system (SPSS), The Chi-square test was performed for assessing the statistical significance of the data values where the descriptive statistics is used., the level of probability at $P$ values below of $<0.05$ was used to identify the significant difference (12) .

\section{Results and Discussion:}

The world's most severe congenital infections are congenital HCMV infections. Infection rates vary across different populations and ages. During pregnancy, reactivated infections or maternal primary infections can lead to congenital HCMV infections, but maternal re-infection with different CMV strains can rarely lead to congenital symptom infections. The aims of this study was to determine the prevalence of viral infections with the congenital Cytomegalic virus infection (HCMV) using ELISA and PCR of HCMV among selected groups of aborted and pregnant women in Hilla hospital in Babylon.

A total of 90 subjects were involved in this study with age ranging 17-45 years old. The aim was to detect and diagnose patients with a current infection of CMV and in aborted and pregnant women. The descriptive analysis of samples manifested that the aborted and pregnant women were aged between 17 
and $45(26.7 \pm 5.6)$. Highly significant differences were detected between the studied groups regarding age (years) distribution as shown in Table 5, eight of women were 17-20 years old, 24 were 20-24 years old, 24 were 25-29 years old, 21 were 30-39 and 13 were above 40 years old. The present study agrees with the study by Anmar et al (13) who found the highest seropositivity (29\%) is shown in the age groups of (20-29) years.

Table 5. The Number and percentage of study group in different age (years)

\begin{tabular}{ccc}
\hline Age (years) group & NO. & $\%$ \\
\hline $15-19$ & 8 & 8.8 \\
$20-24$ & 24 & 26.6 \\
$25-29$ & 24 & 26.6 \\
$30-34$ & 13 & 14.4 \\
$35-39$ & 8 & 8.9 \\
$=>40$ & 13 & 14.4 \\
Total & 90 & $100 \%$ \\
\hline
\end{tabular}

Serological identification of IgG and IgM of CMV

All serum specimens were tested for the presence and determination of HCMV IgG with IgM antibodies infection using ELISA technique. These included (70) women with history of abortions, and (20) normally pregnant as determined control. The results obtained from the serological test were $62(89 \%)$ patients were positive for $\mathrm{IgG}$, while the 65 (93\%) of patients were positive for the IgM. While the results obtained from the control pregnant women were $9(45 \%)$ subjects positive for the IgG and all of control were negative for the $\operatorname{IgM}$, the distribution of $\operatorname{IgG}$ and $\operatorname{IgM}$ antibodies in all patients and ccontrol groups according to serological test is shown in Table 6. Various researches focused on the interaction of pregnant and aborted women with HCMV infections, followed by work on tumor patients and CMV, and other studies with different relationships with the virus were performed. However, the present study showed agreement with several studies in different parts of Iraq, especially in Baghdad city. One of the cases reported by Al-Baiati et al (14) was that 144 abortion women had a positive outcome of $15(10 \%)$ for CMV IgM and 129 (85\%) for CMV IgG antibodies. However, our research agrees with the study done by Majeed (15), who documented the study involving 270 20-35-year-old women.

The results showed that 90 cases were positive for the CMV, 62 of whom were positive for the CMV IgM and 28 for the CMV IgG. Another study was recorded by Hussan (16) revealed that the 44 positive cases of one or more unexplained abortions for the CMV IgM of the 210 women with that background. In the population of pregnant women, the rates of $\mathrm{CMV}$ infections did not rise with ages but were consistently high in women under 30 years of age (60 to $66 \%$ ). Risk factors for CMV infections were associated with group socioeconomic status (17).

HCMV IgM has been shown to peak in the first 1 to 3 months after primary infections in pregnant women and then persists at low levels for 18 to 39 weeks, with detection depending on both individual patients and $\operatorname{IgM}$ antibody assay sensitivity (18).

After the initial infection onsets, the rise in $\operatorname{IgM}$ titer may occur prior to the rise in the $\mathrm{IgG}$ titer, making the CMV IgG avidity test based on the sensitivity of the CMV IgM tests. To ensure that all CMV IgM - positive samples for IgG avidity has been identified and screened.

Table 6. Disruption of the positive and negative samples to HCMV in the miscarriage women and the Control Group detected by ELISA technique

\begin{tabular}{|c|c|c|c|c|c|}
\hline & & Category & $\mathbf{N}$ & $\%$ & Exact Sig. (2-tailed) \\
\hline & & Positive & 62 & 89 & 0.000 \\
\hline CMVIgG & & Negative & 8 & 11 & \\
\hline Aborted & Total & & 70 & 100 & \\
\hline CMVIgM & & positive & 65 & 93 & 0.000 \\
\hline Aborted & & Negative & 5 & 07 & \\
\hline & Total & & 70 & 100 & \\
\hline CMVIgG & & Positive & 9 & 45 & 0.824 \\
\hline Pregnancy & & Negative & 11 & 55 & \\
\hline & Total & & 20 & 100 & \\
\hline CMVIgM & & Negative & 20 & 100 & 0.000 \\
\hline Pregnancy & Total & & 20 & 100 & \\
\hline
\end{tabular}

Statistical significant in $\mathbf{P}<0.05$ 
The present study found in Table 7 that the age group of 20 to 30 years recorded the highest incidence of microbial cytomegalovirus infections could increase the risk of cases of abortion in women, furthermore it is the less efficient as people grow older, and this finding was supported by our research agreement with the findings of the previous study (13) who reported that the majority of HCMV infections occurred in the 20-29 years age group. The occurrence of primary infections of CMV may be due to that most marriages in our population occurred among this age group. In Iraq, our researches have showed that the most common women of gestation ages are seropositive for the CMV and that they deal with the infections either through prenatal or postnatal transmissions or during early childhood. The CMV IgG antibody avidity has been shown to distinguish the primary CMV infections from reactivated infections in pregnant women, in addition, the rates of maturation and duration of the antibody have been shown to be correlated with viremia patients. Low avidities of IgG continue for about 17 weeks in pregnant women, with complete antibodies maturation occurring about 25 weeks after symptom onset (19).

Table 7. Seroprevalence of anti - HCMV according to the Ages Group in Women's

\begin{tabular}{crrrrr}
\hline & \multicolumn{2}{c}{ Anti - HCMV IgG } & \multicolumn{2}{c}{ Anti - HCMV IgM } & Total \\
Age (years) & \multicolumn{1}{c}{ Positive } & \multicolumn{1}{c}{ Negative } & Positive & Negative & \\
\hline $15-19$ & 8 & - & - & 8 & 8 \\
$20-24$ & 21 & 3 & 4 & 20 & 24 \\
$25-29$ & 20 & 4 & 1 & 23 & 24 \\
$30-34$ & 10 & 3 & - & 13 & 13 \\
$35-39$ & 6 & 2 & - & 8 & 8 \\
$=>40$ & 8 & 5 & - & 13 & 13 \\
\hline
\end{tabular}

\section{Molecular Identification of CMV Extraction of Genomic DNA}

In this study, ggnomic DNA was successfully extracted from all samples using a commercial viral Genomic DNA purification Kit as per company instructions. Good extraction results of the DNA quantification (concentration and purity) were directly performed by Nano drop spectrophotometer at 260/280 $\mathrm{nm}$. DNA concentration extracted from all the isolates ranged between ( 58 to 142 ) $\mathrm{ng} / \mu \mathrm{l}$, and the purity was evaluated ranged between (1.8 to 2 ). The DNA extracted was confirmed and analyzed by the horizontal gel electrophoresis in $1 \%$ agarose for 30 min at 75 volts and was exposed to the U.V light where the DNA appears as compact bands, as shown in Fig. 1.

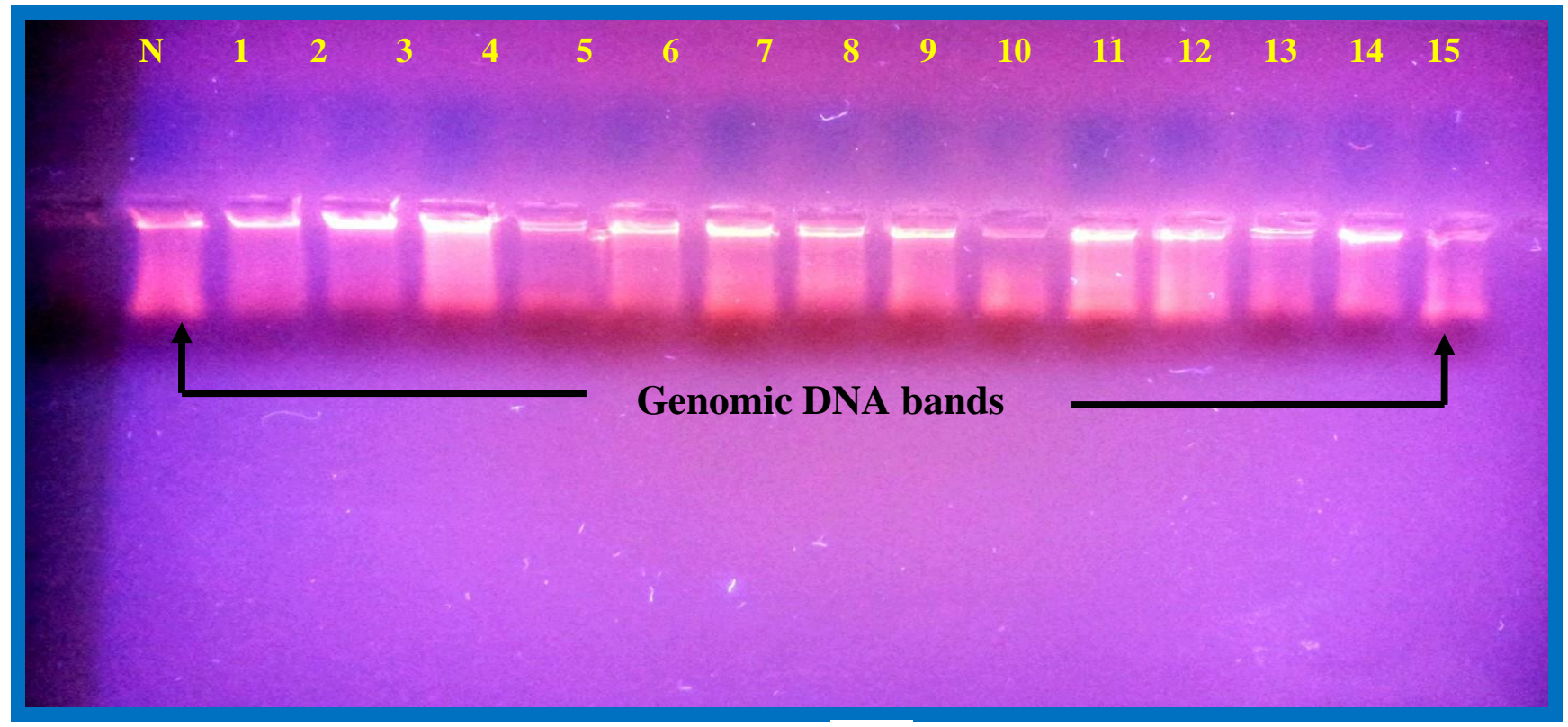

Figure 1. The genomic DNA band extracts from the CMV isolates on (1\% agarose, 75V, for 30 min stained with ethidium bromide). Lane 1-15: DNA of Lane N: Negative control (water). 
CMV found in the blood as suggesting a primary CMV infection $(9,20)$. In the current study, the PCR identified the CMV DNA in women's blood samples with the CMV display reported primary infections as shown in Fig. 2.

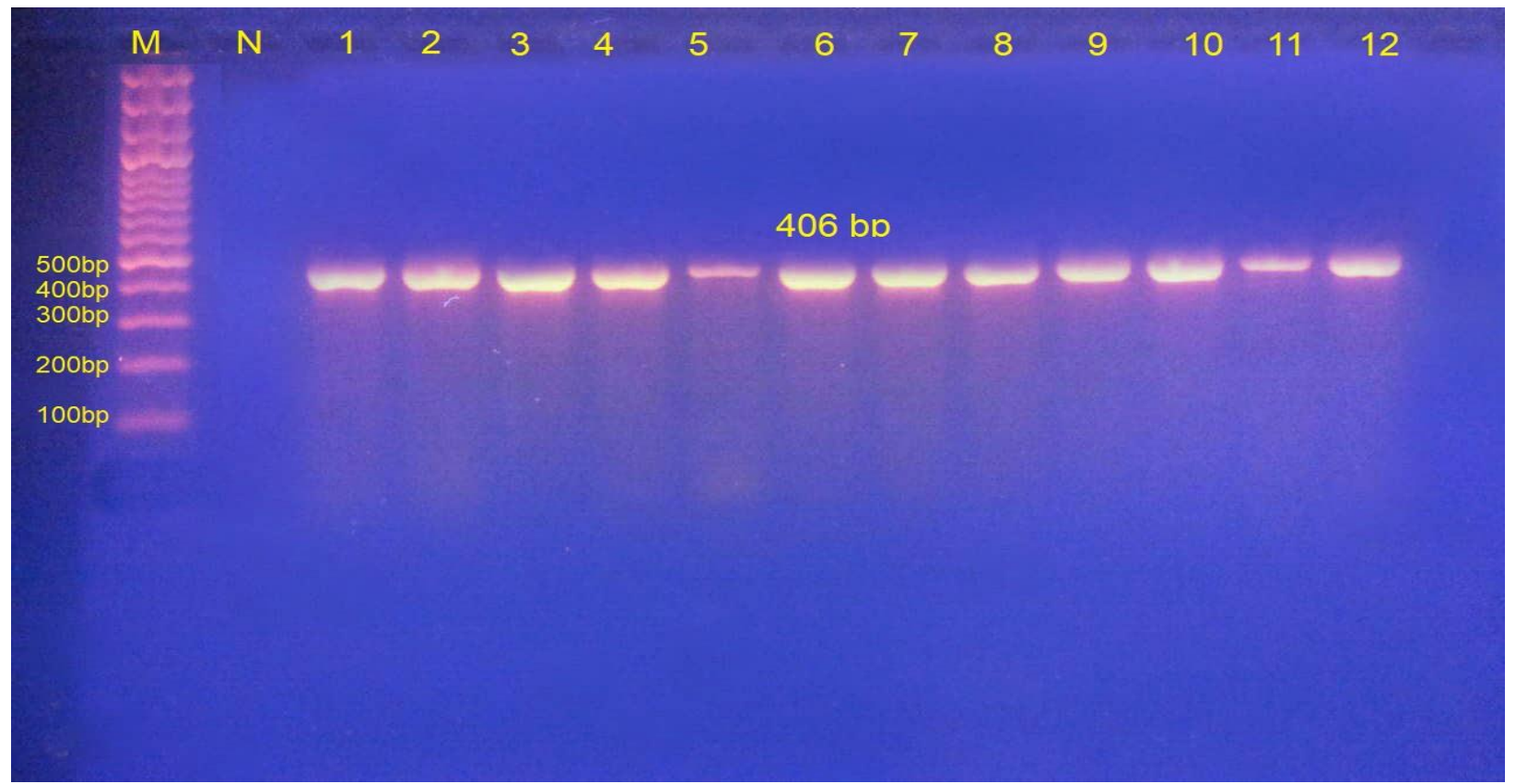

Figure 2. Agarose gel electrophoresis of PCR products (1.5\% agarose, 75 volt for $90 \mathrm{~min})$. Lane (M): (100 bp DNA Ladder). lane N: Negative control. All lanes (1-12) of CMV samples show positive results (amplified size 406 bp).

The results of this study, as shown in Table 8, showed that the frequency of $13(19 \%)$ samples was positive for HCMV-DNA in women of abortion while $3(15 \%)$ was lower than in pregnant women. It is shown that there is no correlation between CMV viremia or the detection of CMV-DNA in the blood and intrauterine transmissions (21). The results obtained in the current study were consistent with other research (22), they found that approximately 30 $(30.7 \%)$ of the samples tested were positive for the viral genome, and differences in such subjects areas could be attributed to samples types or, in some cases, diseases types and the stages (23). In addition, the findings of the present study CMD-DNA were in line with other studies $(20,24)$ found from the nested PCR, showing that the CMV-DNA was identified in the $4(0.4 \%)$ of the 983 cord blood samples. Thanks to its time-saving feature, and high sensitivity and specificity, the PCR has been developed to detect HCMV.

At the time of HCMV outbreaks, the levels of the HCMV-DNA were significantly higher than rates 4 to 12 weeks before the onset of symptoms or than levels associated with the asymptomatic HCMV, probably due to a long duration of replication of the viral genome and possibly other viruses, as has been shown $(25,26)$. The discrepancy between the ELISA test and the conventional PCR technique in the reported results of congenital CMV infections could be due to differences in the methods sensitivity and specificity (24). The optimal diagnostic tests should be reasonably prone to early detection of infections before clinically significant diseases have arisen, and the test will remove false positive findings as well . HCMV-DNA detection is most likely to be useful in this way, as it is highly sensitive and more precise than serological methods by ELISA technique. The positive results of IgM-ELISA and negative DNA may also be due to the presence of IgM antibodies in some apparently healthy individuals for a long time after infection, where the CMV virus load may be too low to be identified by PCR technique.

The Christian et al (9) work documented an extraction method for optimal recovery of CMVDNA from preserved dried blood spots that can be useful for both the identification of the CMV and the genotyping of polymorphic CMV genes in cases of congenital CMV infection. 
Table 8. Seroprevalence of anti-HCMV According to DNA detection using PCR

\begin{tabular}{cccccc}
\hline & & Category & N & Percent \\
\hline \multirow{2}{*}{ Aborted } & & DNA detectable & 13 & & 0.19 \\
women & \multirow{2}{*}{ Total } & DNA not detectable & $\mathbf{5 7}$ & $\mathbf{0 . 8 1}$ & \\
& & & $\mathbf{7 0}$ & $\mathbf{1 . 0 0}$ & \\
Pregnancy & & DNA detectable & $\mathbf{3}$ & $\mathbf{0 . 1 5}$ & \\
women & Total & DNA not detectable & 17 & $\mathbf{0 . 8 5}$ & \\
& & & 20 & 1.00 & \\
\hline
\end{tabular}

\section{Conclusion:}

This study summarized that there are increasing seropositive rates for the HCMV among aborted and pregnant women. The evaluation of prevalence of HCMV disease and routine screening for HCMV infection should be introduced for pregnant women in this setting. It is vital to initiate further research work with many samples from different area to assess prevalence, characterize HCMV, and evaluate its maternal health implications.

\section{Authors' declaration:}

- Conflicts of Interest: None.

- We hereby confirm that all the Figures and Tables in the manuscript are mine ours. Besides, the Figures and images, which are not mine ours, have been given the permission for re-publication attached with the manuscript.

- The author has signed an animal welfare statement.

- Ethical Clearance: The project was approved by the local ethical committee in University of $\mathrm{Al}-$ Qasim Green.

\section{References:}

1. Beam E, Razonable R R. Cytomegalovirus in solid organ transplantation: epidemiology, prevention, and treatment. Curr. Infect. Dis. Rep. 2012; 14 (6): 633641. doi: 10.1007/s11908-012-0292-2

2. Fabbri E, Revello MG, Furione M, Zavattoni M, Lilleri D, Tassis B, et al. Prognostic markers of symptomatic congenital human cytomegalovirus infection in fetal blood. BJOG: Int J Gynaecol Obstet. 2011 Mar; 118 (4):448-56.

3. Sen M R, Shukla B N, Tuhina B. Prevalence of serum antibodies to TORCH infection in and around Varanasi, Northern India. J Clin Diagn Res. 2012; 6(9):1483-5.

4. Abbas N R, Jameel YM, Mahdi AH. Relationship between increases anticardiolipin titer with CMV infection in pregnant women. Diyala J. of Medicine. 2017; 12(2): 1-6.

5. Yu Q, Sharma A, Oh SY, Moon HG, Hossain MZ, Salay TM, et al. T cell factor 1 initiates the T helper type 2 fates by inducing the transcription factor GATA-
3 and repressing interferon-gamma. Nat. Immunol.; 2009. 10, 992-999.

6. Fakhreddine AY, Frenette CT, Konijeti GG. A practical review of cytomegalovirus in gastroenterology and hepatology. Gastroenterology research and practice. 2019 Mar 7; 2019.

7. Ebina Y, Minematsu T, Morioka I, Deguchi M, Tairaku $\mathrm{S}$, Tanimura $\mathrm{K}$, et al. Rapid increase in the serum cytomegalovirus IgG avidity index in women with a congenitally infected fetus. J Clin Virol.; 2015. 66:447.

8. Vora SB, Brothers AW, Waghmare A, Englund JA. Antiviral combination therapy for cytomegalovirus infection in high-risk infants. Antivir. Ther. (Lond.).2018; 23 (6): 505-511. doi: 10.3851/IMP3238

9. Berg C, Friis MB, Rosenkilde MM, Benfield T, Nielsen L, Lüttichau HR, Sundelin T. Development of highly efficient protocols for extraction and amplification of cytomegalovirus DNA from dried blood spots for detection and genotyping of polymorphic immunomodulatory genes. PLoS One. 2019 Sep 12; 14(9):e0222053.

10. Smith JS, Robinson NJ. Age-specific prevalence of infection with herpes simplex virus types 2 and 1: a global review. J. Infect. Dis. 2002; 186 (Suppl 1): S328.

11. Hadi L, Zahra G, Mohammad JH, Esmail. S. Development of PCR assay for early detection of CMV infection in renal transplant recipients, Nephro-Urol Mon. 2012; 3(2):106-108

12. Urdan TC. Statistics in Plain English, 2nd ed. Lawrence Erlbaum Associates, London. 2005. 130-143.

13. Al-Taie AA, Abdullah BA, Al-Attar MY. Serological and molecular comparison study for diagnosis of cytomegalovirus infection in aborted pregnant women in Iraq. Microbiology/Special Issue for the Third Scientific Conference of Biology, Raf. J. Sci. 2018; 27(5)49-77.

14. Al-Baiati HAM, Muhsin MA, Jabbarb RN. Seroprevalence of Human Cytomegalovirus (HCMV) in aborted women in Baghdad province. Int $\mathbf{J}$ Curr Microbiol Appl Sci. 2014; 3(2):97-102.

15. Majeed AKh. Toxoplasma gondii and cytomegalovirus seropositivity pathogens in high- risk patients in Iraq. Al-Anbar J Vet Sci. 2011; 4(1):41- 49.

16. Hussan BM. Study the Prevalence of ACL, APL, CMV, HSV, Rubella and Toxoplasma gondii in 
aborted women in Baghdad. Med. J. Babylon. 2013. 10 (2):455-464.

17. Fowler KB, Stagno S, Pass RF. Maternal age and congenital cytomegalovirus infection: screening of two diverse newborn populations, 1980-1990. J. Infect. Dis. . 1993 Sep 1; 168(3):552-6.

18. Revello MG, Gerna G. Diagnosis and management of human cytomegalovirus infection in the mother, fetus, and newborn infant. Clin. Microbiol. Rev. 2002; 15:680-715

19. Tanimura K, Tairaku S, Morioka I, Ozaki K, Nagamata S, Morizane M, Deguchi M, Ebina Y, Minematsu T, Yamada H. Universal screening with use of immunoglobulin $\mathrm{G}$ avidity for congenital cytomegalovirus infection. Clin. Infect. Dis. 2017 Oct $30 ; 65$ (10):1652-8.

20. Saldan A, Forner G, Mengoli C, Gussetti N, Palù G, Abate D. Testing for cytomegalovirus in pregnancy. J Clin Microbiol. 2017 Mar 1; 55(3):693-702. doi:10.1128/JCM.01868-16

21. Revello MG, Zavattoni M, Sarasini A, Percivalle E, Simoncini L, Gerna G. Human cytomegalovirus in blood of immunocompetent persons during primary infection: prognostic implications for pregnancy. J. Infect. Dis. 1998 May 1; 177 (5):1170-5.

22. Enan KA, Rennert H, El-Eragi AM, El Hussein AR, Elkhidir IM. Comparison of Real-time PCR to ELISA for the detection of human cytomegalovirus infection in renal transplant patients in the Sudan. Virol J. 2011 Dec $1 ; 8(1): 222$.

23. AL-Khaweledy AJ, AL-Ammar MH, AL-Khozai M. Cytomegalovirus infections are the most common infection among patients with renal failure at AL-Najaf province. Photon. J. Microbiol. 2014; (107):200-206.

24. Al-Awadhi R, Al-Harmi J, Al-Fadhli S. Prevalence of Cytomegalovirus DNA in Cord Blood and Voided Urine Obtained from Pregnant Women at the End of Pregnancy, Med Princ Pract. 2013; 22:194-199. DOI: $10.1159 / 000343167$.

25. Mariam KM, Ghanima SM, Mohammed ST. Studying the ability of transformation of lymphocytes by using PHA in patient with Cytomegalovirus. Baghdad Sci. J 2010; 7(1): 334-340.

26.Zgair A.K., Ali L.K., Zgair M.K., Farah MS. Estimation of LgM-anti HEV rubella and cytomegalovirus in the sera of aborted women. Um Salama Sci. J, .2006; 3: 445-448. 
التشخيص المناعي والجزيئي لعدوى الفيروس المضخم للخلايا بين النساء المجهضات والحوامل في مدينة بابل

حيدر تركي موسى الموسوي2
قبس نعمة هادي الحجار 1

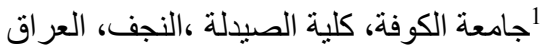
2² كلية التقانات الاحيائية، جامعة القاسم الخضر اءو، بالبل، العراق.

الخلاصة

الفبروس المضخم للخلايا البشرية (CMV) هو من ضمن فيروس الهربس و السائد بصورة عالية في جميع أنحاء العالم. وفقا لمركز

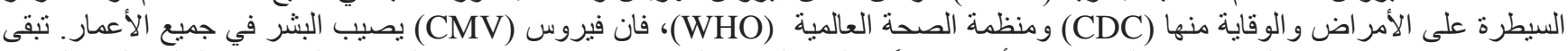

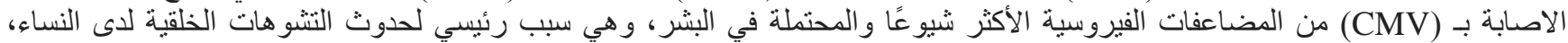

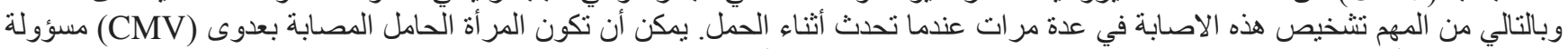

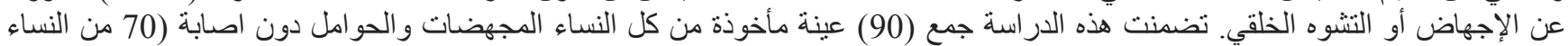

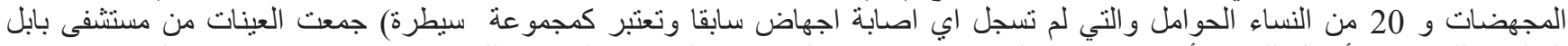

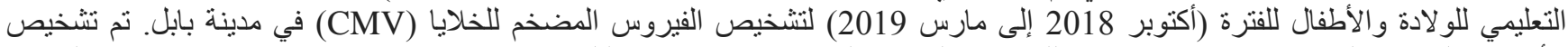

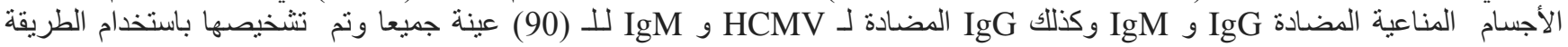

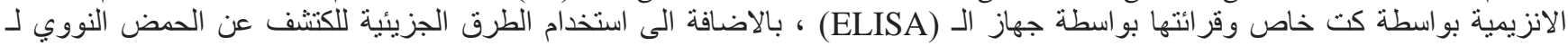

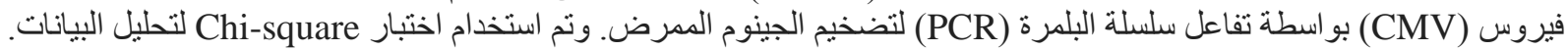

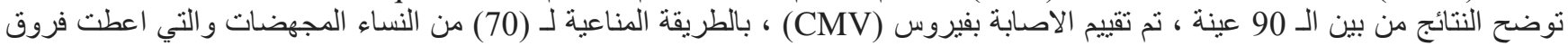

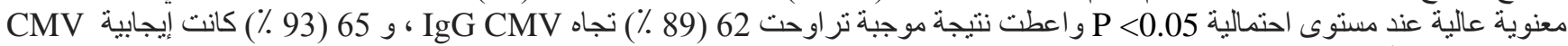

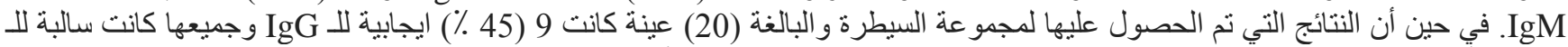

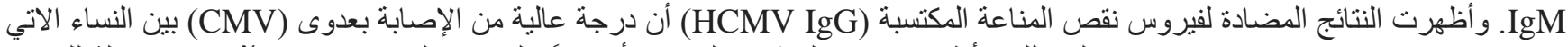

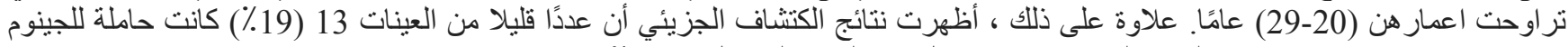
HCMV DNA نم اكتشافها في النساء المجهضات بينما اقل عند النساء الحو امل 3 (15\%).

الكلمات المفتاحية: الفيروس المضخم للخلايا البشرية (HCMV) ؛ الإجهاض؛ الأجسام المضادة IgM و IgG ؛ المضاد IgM ؛ IgM IgG .DNA-HCMV g 